\title{
INCORPORACIÓN DE AZUFRE Y YESO EN SUELO SALINO-SÓDICO: SU EFECTO SOBRE EL RENDIMIENTO Y CALIDAD DE LECHUGA BAJO INVERNADERO
}

\author{
Longo, A. ${ }^{1}$; Ferratto, J. ${ }^{2}$; Mondino, M. C. ${ }^{3} \&$ Grasso, R. ${ }^{3}$
}

\section{RESUMEN}

En los suelos de los invernaderos pueden incorporarse sales y/o sodio con el agua de riego. El objetivo del presente trabajo fue evaluar la incidencia de la incorporación al suelo de yeso y de azufre sobre las condiciones químicas del mismo y la productividad del cultivo de lechuga bajo en invernadero.

Se cultivó lechuga durante nueve ciclos consecutivos, en Rosario. Los tratamientos fueron: Testigo; Yeso $(2.500 \mathrm{~kg} / \mathrm{ha})$ y Azufre $(2.500 \mathrm{~kg} / \mathrm{ha})$. Se realizaron tres repeticiones, las cuales se evaluaron por análisis de variancia. Las variables analizadas fueron: rendimiento; calidad y condiciones químicas del suelo.

El azufre presentó diferencias altamente significativas en calidad y rendimiento. En un primer momento el pH sufrió una disminución y luego a medida que avanzó el ensayo a valores similares del inicio. La conductividad eléctrica aumentó en todos los tratamientos, pero en mayor medida en el azufre. La incorporación de azufre permite aumentar los rendimientos y la calidad en lechuga, en suelos salino-sódico.

Palabras clave: enmiendas, suelo sódico, invernadero, lechuga.

\section{SUMMARY}

Incorporation of sulphur and gypsum into saline-sodium soils: Effect to the rate of productivity of greenhouse lettuce.

Greenhouse soils usually have problems of salt accumulation whith water irrigation. The incorporation of chemical amendments would improve this situation. The objective of this work was to evaluate the incidence of gypsum and sulphur in the soil chemical properties and the productivity of greenhouse lettuce.

Nine lettuce crops were carried out in Rosario. The treatments were: Control, Gypsum ( $2500 \mathrm{~kg} /$ ha) and Sulphur (2500 kg/ha), replicated three times. They were evaluated according to the ANOVA.

1.- Facultad de Ciencias Agrarias, Universidad Nacional de Rosario. AER INTA Arroyo Seco. Agente de Proyecto Cambio Rural. 9 de Julio 530. (2128) Arroyo Seco, Santa Fe. Email: alelongo@arnet.com.ar 2.- Investigador de CIURN. Facultad de Ciencias Agrarias (UNR). Proyecto Hortícola Rosario.

3.- Facultad de Ciencias Agrarias (UNR). Proyecto Hortícola Rosario.

Manuscrito recibido el 29 de setiembre de 2005 y aceptado para su publicación el 27 de febrero de 2006. 
The variables analized were: yield, lettuce quality and chemical soil properties.

Sulphur showed highly significant differences in relation to quality and rate of productivity when compared to check and gypsum. The $\mathrm{pH}$ slowed down at the beginning and the was reestablished to the initial values an the end of the experiment. The incorporation of sulphur increases not only the rate of productivity but also the quality of the lettuce in saline-sodium soils.

Key words: soil amend, degraded soils. 